DOI: $10.17805 / z p u .2015 .3 .8$

\title{
Либерализация половой морали в современном мире
}

\author{
Д. А. ТИХОМИРОВ \\ (РОССИЙСКИЙ ЭКОНОМИЧЕСКИЙ УНИВЕРСИТЕТ ИМ. Г. В. ПЛЕХАНОВА)
}

В статье рассматривается процесс либерализации половой морали в современном мире. Показывается, что нормативные представления о сексуальных отношениях значительно отличаются в различных культурах, которые, выстраивая границы допустимого сексуального поведения, поддерживают тем самым свою социальную устойчивость. В западном обществе половая мораль, опирающаяся на христианское учение, хотя и регулярно нарушаемая его членами, сохранялась стабильной на протяжении веков. Индивиды, нарушая установленные нормы в сексуальной сфере, не пытались разрушить весь нормативный порядок. Однако во второй половине XX в. произошли радикальные изменения, разрушившие многие основополагающие ценностно-нормативные структуры, определяющие поведение человека. Сначала молодежная гетеросексуальная революция 1960-х годов, имеющая преимущественно женское лицо, порвала нормативную связь сексуальности, брака и рождаемости, а в конце XX - начале XXI в. гомосексуальная революция окончательно деформировала традиционную половую мораль.

Страны Запада охватывает волна конституирования нетрадиционных сексуальных отношений в качестве не только неформальной, но и формальной нормы. Сформированное общественное мнение стало влиять на приятие определенных решений, затрагивающих интересы ЛГБТ-сообщества, которые начинает все активнее навязывать свою культуру различным индивидам, социальным группам и социуму в целом. Несогласные с новыми правилами все чаще подвергаются различным санкциям. Гомосексуализм переходит из социокультурной области в политическую, входя в орбиту геополитических интересов стран Запада.

В отличие от Европы и США, в которых развертывается либерализация половой морали (хотя и в них не наблюдается однородной позиции), в ряде стран остального мира разворачивается противоположная тенденция. В данной статье особое внимание уделяется России. Автор, анализируя результаты опросов общественного мнения по проблеме гомосексуализма, проведенные в течение последних десятилетий, показывает не только сохранение, но и нарастание негативного отношения россиян к этому явлению, которое воспринимается как явная девиация, что противоречит мировой тенденции либерализации половой морали.

Ключевые слова: половая мораль, либерализация половой морали, общественное мнение, сексуальная революция, нетрадиционные сексуальные отношения, гомосексуализм. 


\section{ВВЕАЕНИЕ}

$\mathbf{R}$ Аанной статье мы рассмотрим трансформацию половой морали, которая обусловливает значительные социальные изменения в странах Запада.

Сам термин «половая мораль» непосредственно связан со своим родовым понятием. В «Социологической энциклопедии» мораль (от лат. moralis - нравственный) трактуется в двух смыслах: во-первых, как этическая категория, определяющая важнейший способ регуляции отношений в обществе, совокупность ценностей и норм, которые ориентируют людей на поведение в соответствии с принятым в обществе представлением о добре; во-вторых, как «особая форма общественного сознания и вид общественных отношений (моральные отношения), которая возникла из необходимости регулировать взаимоотношения людей в человеческом общежитии, согласовывать их действия, поступки для сохранения целостности определенной социальной общности» (Тайдаков, Цветкова, 2003: 683-684). Исходя из этого определения, мы понимаем половую мораль как систему сексуальных ценностей, норм и установок, которая ориентирует людей на определенные взгляды и поведение в сфере половых отношений. Половая мораль выполняет важную функцию регуляции сексуальных отношений, поддерживая тем самым социальную устойчивость общества. В отличие от закрепленных в различных нормативных документах формальных норм мораль (в том числе и половая) выступает как «неписаный закон», опирающийся на силу общественного мнения. Мораль передается от поколения к поколению в процессе социализации и является основой ценностного ядра личности и общества в целом (Ковалева, 2012; Ковалева, Ауков, 2012).

Половая мораль, содержащая наиболее важные представления (с точки зрения общества) об интимной стороне жизни человека, всегда была связана с определенными ограничениями в сфере сексуальных отношений. Хотя сексуальное желание как биологическая составляющая природы человека может быть направлено на различные объекты, что довольно ярко показано антропологическими исследованиями, проведенными в обществах, которые сегодня принято относить к дописьменным (простым). В этих архаичных культурах можно встретить нормативные представления о сексуальном поведении, значительно отличающиеся от привычных для западной культуры, что нередко вызывает удивление и непонимание у стороннего наблюдателя. Однако любая культура накладывает социальные путы на возможные проявления человеческой сексуальности. В каждой культуре они свои, связанные с типичными тезаурусными структурами. А непривычные воспринимаются как чужые/чуждые или просто как отклонения.

В дилемме «норма - отклонение» тезаурусный анализ, разработанный Вал. А. и Вл. А. Ауковыми, вычленяет связь нормы и базовой оси тезауруса «свой - чужой чуждый» (Ауков В., Ауков Вл., 2008, 2013). При этом существенным оказывается построение тезауруса не вокруг понятийных рядов, а вокруг концептов - таких ментальных образований, в которых логика понятия соединена с образом и әмочиональной реакиией на него (Ауков В., Ауков Вл., 2013: 75). В этом ракурсе нормой становится не только институционализированное установление, не только ожидаемое в обществе (сообществе) поведение индивида, но и некое выражение связи освоенной субъектом части реальности, ядром которой в сознании становится картина мира. Существо этой связи может быть уяснено как соответствие оцениваемого на предмет «нормы - отклонения» явления, процесса, свойства этой картине мира. Специфично этот процесс оценивания проходит в молодежной среде (Ауков, 2012: 403-405; Погор- 
ский, 2012, 2013), он в значительной мере опирается на сближение/противостояние культурным картинам мира, распространенным в данном обществе (Кузнецова, $\Lambda$ ков, 2009). Именно в силу этого тезаурусный подход позволяет увидеть приемлемость в сфере семейно-брачных отношений самых разных моделей поведения и оценки: даже самые экзотические - с точки зрения стороннего наблюдателя - институциональные формы брачного ухаживания, вступления в брак, сексуальной жизни вне брака, развода и т. п. оказываются для «своих» совершенно достаточными для ориентации во внешней среде и поддержания жизнеспособности общества как биосоциальной общности (Тихомиров, 2009; Ауков, Тихомиров, 2012).

Характерно в этом отношении и замечание П. Бергера и Т. Аукмана: «...хотя у человека есть сексуальные влечения, сопоставимые с имеющимися и у других высших млекопитающих, человеческая сексуальность характеризуется очень высокой степенью пластичности. Она не только относительно независима от временных циклов, но и пластична в отношении как объектов, на которые может быть направлена, так и форм проявления. Этнологические данные свидетельствуют о том, что в сексуальных отношениях человек способен почти на все... Если термином “нормальность” называют то, что является антропологической необходимостью, или то, что универсально для данной культуры, тогда ни сам этот термин, ни его антоним неприменимы к многообразию форм человеческой сексуальности. В то же время человеческая сексуальность, конечно же, управляема, иногда строго упорядочена в каждой конкретной культуре. В каждой культуре - свои, весьма различные формы, проявления сексуальности, специфические образцы сексуального поведения и “антропологические” предпосылки в сексуальной сфере. Эмпирическая относительность всех этих форм, их огромное разнообразие и блестящая изобретательность в данной сфере указывают на то, что все они - скорее продукт созданных человеком социокультурных образований, нежели биологической человеческой природы» (Бергер, Аукман, 1995: 86).

\section{ПОАОВАЯ МОРААЬ: УСТОЙЧИВОСТЬ И ИЗМЕНЧИВОСТЬ}

Половая мораль, необходимая для регуляции сексуальных отношений, на протяжении веков оставалась практически неизменной. Она основывалась на христианском учении о взаимоотношениях полов. Общество в лице различных его институтов поддерживало стабильность половой морали, поскольку она непосредственно касалась воспроизводства населения. Надо отметить, что индивиды всегда нарушали те или иные нормы в сексуальной сфере, но делали это скрыто, тогда как явно признавали важность основополагающих ценностей и не стремились разрушить нормативный порядок. А общество при этом следило за основными правилами игры, смотря сквозь пальцы на некоторые нарушения. Так, например, норма добрачного целомудрия (или супружеской верности) предписывалась обоим полам, однако отклонение от нее совершенно по-разному воспринималось общественным мнением. Если мужчина и женщина утрачивали невинность до брака, то он в основном отвечал перед судом своей совести, а она, помимо этого, подвергалась всей силе общественного порицания. Высокая значимость этой нормы для девушки получила отражение в специальных свадебных ритуалах проверки девственности невесты, выполняющих важную функцию социального контроля.

Различные отклонения от норм половой морали встречаются в автобиографических произведениях А. Августина (354-430), П. Абеляра (1079-1142), Ж.-Ж. Руссо (1712-1778), М. Н. Толстого (1828-1910) и Аругих авторов (Августин, 2014; Абеляр, 
2014; Руссо, 2014; Толстой, 2014). Причем сексуальное поведение получало негативные оценки в их собственном восприятии, т. е. они понимали, что, нарушая нормы половой морали, поступают плохо, но не меняли свое поведение. Здесь прослеживается явный конфликт между природой человека и культурой, которая среди прочих своих функций имеет и сдерживание человеческой природы, обуздание биологических потребностей индивида в интересах поддержания социального целого. Вопрос, поставленный в начале $\mathrm{XX}$ в. 3. Фрейдом о возможности нахождения такого состояния в развитии общества, когда будет обеспечена гармония между природой индивида и культурой, до сих пор остается открытым. Хотя поиски такого существования постоянно ведутся. Нередко это выливается в революционные изменения в сфере сексуальных отношений и их признание как нормы или, по крайней мере, допустимой вариации нормы.

\section{НОВЫЙ ВЕКТОР СЕКСУААЬНОЙ РЕВОАЮЦИИ}

Первая сексуальная революция в XX в. произошла в России после революции 1917 г. Прежняя половая мораль, репрессивная по отношению к женщине, была разрушена, а новая на протяжении десятилетия олицетворяла собой анархическую свободу сексуальных отношений. Аобрачные половые связи, всевозможные формы брака (полигамный, незарегистрированный и т. п.) получили широкое распространение. Однако негативные демографические последствия сексуальной свободы заставили власть уже в 1930-х годах проводить политику, направленную на укрепление социального института семьи и воссоздание многих основополагающих ценностно-нормативных структур, регулирующих семейно-брачные отношения. Возрожденная традиционная мораль просуществовала до конца века, когда она, как и вся социальная система, была деформирована новыми радикальными преобразованиями. Но перед этим в 1960-х годах в США, а потом и в других странах Запада разразилась сексуальная революция, которая разорвала нормативную связь сексуальности и брака. Молодежный бунт против нормативного порядка старших поколений привел к значительным сдвигам как в сексуальном поведении, так и в половой морали. Сексуальные отношения за рамками брака стали восприниматься как социальная норма. Аиберализация охватила и эту сторону человеческой жизни.

Сексуальность все более освобождается от моральных пут, а индивиды все реже готовы следовать ограничениям, накладываемым социальными структурами. Так, например, онлайн-опрос почти 10 тыс. католиков, проведенный Союзом католической молодежи Германии в 2013 г., показал, что молодежь знакома с отношением Церкви к браку и семье, но учение Церкви о половых отношениях не играет никакой роли для 9 из 10 молодых католиков. Исследование отчетливо акцентировало различие между христианским учением и повседневной жизнью католиков. Следуя своим влечениям и сталкиваясь с церковными ценностями, молодые люди часто отворачиваются от Церкви. Коррозия моральных представлений настолько сильно проникла в фундаментальные социальные устои, что все меньше вызывает удивление позиция большинства опрошенных католиков о необходимости церковного венчания однополых пар (9 из $10 \ldots, 2014:$ Электронный ресурс).

Ииберализация половой морали продолжает развертываться и в XXI в. Если в 1960-х годах западный мир столкнулся с молодежной гетеросексуальной революцией, то сегодня с полным основанием можно говорить о гомосексуальной революции. 
Страны Запада охватывает волна конституирования нетрадиционных сексуальных отношений. Причем социальные изменения половой морали, происходящие под эгидой прав человека и прогресса, набирают все более высокие обороты, стремительно ускоряя свой темп и охватывая все новые страны, которые еще совсем недавно считались поборницами традиционных католических ценностей. Примером может служить Ирландия, в которой в мае 2015 г. 62\% населения (при 60\%-ной явке) проголосовали на референдуме за легализацию однополых браков (Ирландцы .., , 2015: Электронный ресурс). Напомним, что до 1993 г. гомосексуализм в Ирландии признавался преступлением, а страна традиционно считается одной из самых консервативных в Европе. Ситуация примечательна и тем, что этот референдум был первым в своем роде, когда решение было принято не органами власти, как это происходило в других странах, а населением посредством демократической процедуры, что может создать опасный прецедент. Референдум в Ирландии побудил австралийских геев провести публичные массовые акции в поддержку аналогичного опроса в Австралии. Результаты исследования 2014 г. показали, что легализацию однополых браков поддерживают более $70 \%$ австралийцев. Однако премьер страны Т. Эббот заявил, что в правительстве пока не поддерживают идею референдума. Тем не менее решение о легализации гей-браков может быть принято другим путем, поскольку в угоду политическим интересам лидер оппозиционной Аейбористской партии Австралии Б. Шортен внес соответствующий законопроект на рассмотрение в парламент (Референдум ... , 2015: Электронный ресурс).

Ирландия стала 13-й страной в Европе, в которой однополые браки легализованы (наряду со Словенией, Аанией, Исландией, Францией, Нидерландами, Норвегией, Швецией, Португалией, Бельгией, Аюксембургом, Испанией и Великобританией). Кроме того, на Мальте их признают, если они заключаются за рубежом, а в Финляндии однополые браки будут узаконены в 2017 г. (В Ирландии ..., 2015: Электронный ресурс). Причем такие изменения происходят по инициативе самих граждан, при их непосредственном политическом участии в жизни страны. Так, в Финляндии в конце 2014 г. парламент одобрил поправки в закон «О браке», разрешающие однополые браки (за принятие соответствующего решения высказался 101 депутат, а 90 - против). Закон о легализации однополых браков стал первым в истории страны принятым по инициативе самих граждан: под соответствующей законодательной инициативой подписались 167 тыс. граждан, хотя по регламенту достаточно было собрать 50 тыс. подписей (В Финляндии ..., 2015: Электронный ресурс).

После референдума в Ирландии Европа по вопросу легализации однополых браков разделилась на три зоны. Скандинавия и Западная Европа до Рейна допускают однополые браки. Германия и большая часть Центральной Европы, в том числе Чехия, имеют другие узаконенные формы союзов. Хотя в Чехии общественное мнение уже готово к легализации однополых браков: по данным центра опросов CVVM, за такие браки высказывается большинство чехов (Климеш, 2015: Электронный ресурс). А Италия и восточные страны: Польша, Словакия и большая часть Прибалтики - пока находятся в арьергарде этого «прогрессивного» общественного движения за права человека и борьбу с дискриминацией. Однако вряд ли можно полагать, что традиционные ценности устоят под напором все шире развертывающейся глобализации идей, принимающей форму идеологической диктатуры, непосредственно связанной с политическими интересами. Права человека во всем их многообразии становятся новым политическим оружием и предлогом для отнесения той или иной страны к раз- 
ряду антидемократических государств с необходимостью изменения политического режима в ней посредством смены правительства, в том числе и революционным путем, направленным и активно поддержанным другими государствами, олицетворяющими собой «свободу, прогресс и счастье».

В этой связи не случайным представляется появление в 2015 г. в Госдепартаменте США новой должности - специального посланника США по правам лесбиянок, геев, бисексуалов и трансгендеров (АГБТ). Первым посланником стал Р. Бери, на которого возложена координация внутренней политики Госдепа в отношении служащихгомосексуалистов, а также он будет курировать программы и политические акции департамента, касающиеся прав $\Lambda$ БТ в других странах, работая с правительствами, представителями бизнеса и гражданским обществом (Куприянов, 2015: Электронный ресурс).

В самих США однополые браки были легализованы в июне 2015 г., когда Верховный суд снял запрет на однополые браки в 14 штатах, где он еще сохранялся. В пользу данного решения высказались пятеро членов Верховного суда, другие четверо голосовали против (Верховный суд ..., 2015: Электронный ресурс). Комментируя решения суда, госсекретарь США Аж. Керри подчеркнул, что отныне американское правительство будет добиваться таких же прав для представителей $\Lambda$ БТ-сообщества в других государствах. В официальном заявлении чиновника говорится, что «решение суда посылает ясный сигнал во все части света: никакой закон, основанный на дискриминации, не устоит перед волной справедливости» (Керри ..., 2015: Электронный ресурс).

Обратим внимание на высокую скорость социальных изменений. Первым штатом, разрешившим людям одного пола вступать в брак, в 2004 г. стал Массачусетс. К 2015 г. таких штатов насчитывалось уже 36. Решения властей о легализации однополых браков подкреплены общественной поддержкой. Опрос, проведенный Gallup в 2015 г., выявил значительные сдвиги в общественном мнении за полтора десятилетия. Так, если в 1999 г. за легализацию однополых браков высказались только 27\% респондентов, то в мае 2015 г. таких уже насчитывалось 60\% (Верховный суд ..., 2015: Электронный ресурс).

Сформированное общественное мнение стало влиять на приятие определенных решений, затрагивающих интересы $\Lambda$ БТ-сообщества, которые начинает все активнее навязывать свою культуру различным индивидам и социальным группам. Моральная структура общества разрушена, а сторонники традиционных ценностей, которые не согласны с новыми правилами, все чаще подвергаются различным санкциям. Различные организации (гостиницы, пекарни, фотоателье и др.) за отказ в оказании услуг однополым парам все чаще сталкиваются с судебным преследованием, угрожающим их функционированию, нередко приводя к закрытию бизнеса (В США ..., 2013: Электронный ресурс). Однако пострадать можно не только за поведение, но и за взгляды. B 2014 г. исполнительный директор компании Mozilla Б. Айк испытал на себе санкционное давление за нонконформизм во взглядах. Он подал в отставку после разразившегося скандала, инициированного гей-активистами и поддержанного общественностью, в связи с его неприятием однополых браков, а председатель правления М. Бейкер была вынуждена принести извинения $\Lambda$ ГТ-сообществу за назначение Айка на этот пост. Примечательно и то, что сразу после назначения Айка на эту должность трое членов совета директоров компании подали в отставку (Глава Mozilla ... , 2014: Электронный ресурс). Аиберализация отношения к гомосексуализму в общественном 
мнении стран Запада воспринимается как проявление свободы и прав человека (о чем постоянно напоминают политики и гей-активисты), становясь атрибутом западной демократии.

Проблема нетрадиционных сексуальных отношений в последние десятилетия находится в фокусе СМИ, художественной литературы и кинематографа, получая позитивный окрас и непосредственно влияя на общественное мнение. Выдвижение на передний план сюжетов, связанных с гомосексуальными связями, принимает черты пропаганды әтого социального явления. В массовом сознании складывается представление о большом количестве людей нетрадиционной сексуальной ориентации. Так, в ходе опроса Gallup 2015 г. (Newport, 2015: Электронный ресурс) выяснилось, что американцы причисляют к гомосексуалистам почти четверть граждан США (23\%). Такие оценки сильно завышают реальное число взрослых американских гомосексуалистов, которых вместе с бисексуалами и трансгендерами, по данным социологов, 3,8\%. Наиболее точные оценки дали респонденты с высшим образованием. При этом чаще других завышают число геев и лесбиянок молодые люди (Американцы ..., 2015: Электронный ресурс). Приведенные цифры являются еще одним тревожным признаком размывания моральных представлений. Гомосексуализм в общественном мнении переходит из разряда девиации и маргинального типа поведения, присущего незначительному числу индивидов, в норму, поскольку приобретает столь массовый характер в оценках респондентов. Широкое распространение социального явления придает ему нормативные очертания, раздвигая рамки допустимого поведения.

\section{АИАЕММА «ЗАПАА - ВОСТОК» В СФЕРЕ ПОАОВОЙ МОРААИ}

Аиберализация половой морали происходит преимущественно в странах Запада, но и они не выказывают однородную позицию по этому вопросу, что проявляется в отличиях как между странами, так и между различными социальными группами внутри одной страны. Примерами этого могут служить не только страны Восточной Европы, особенно Россия, в которой гомосексуальные отношения воспринимаются как ярко выраженная девиация, но и США или Финляндия, в которых легализация однополых браков была одобрена благодаря незначительному перевесу сторонников этой идеи над ее противниками при голосовании судей (5 против 4 в США) или депутатов (101 против 90 в Финляндии). Ауховный кризис и разложение моральных основ, присущие западной цивилизации, негативно воспринимаются в остальной части мировой системы, особенно в исламской среде, в которой в ответ на проникновение западных ценностей расширяется территория распространения радикального ислама, на которой установлены религиозные нормы с жестокими санкциями за их нарушение. Не случайно, что террористическое государство ИГИА (Исламское государство Ирака и Аеванта) пополняется все большим количеством молодых и зачастую довольно успешных людей из стран Запада, которых привлекает идеологическое содержание, позволяющее человеку обрести нематериальный смысл и цель своей жизни, отстаивать идеи социальной справедливости и следовать традиционным моральным ориентирам.

В отличие от Европы и США, в которых развертывается либерализация половой морали, в ряде стран остального мира наблюдается противоположная тенденция. Индия в декабре 2013 г. восстановила уголовную ответственность за гомосексуализм. В Брунее в мае 2014 г. вступил в действие новый Уголовный кодекс, основанный на за- 
конах шариата, согласно которому мужчин и женщин-гомосексуалистов ждет суровое наказание вплоть до забивания до смерти камнями. Гамбия приняла закон о пожизненном заключении для гомосексуалистов. В Малайзии содомия, или «непристойности, совершенные с другим лицом мужского пола», караются наказанием до 20 лет лишения свободы, штрафом и поркой. В Ямайке за гомосексуальную связь полагается 10 лет тюрьмы.

Обобщенные данные свидетельствуют, что из стран - членов ООН в 2014 г. в 78 странах сохранялась правовая оценка однополых контактов как противозаконных, при этом в пяти странах (Иран, Иемен, Мавритания, Саудовская Аравия, Судан), а также в некоторых регионах Нигерии и Сомали наказывались смертной казнью (Itaborahy, Zhu, 2014: 18). Через год число стран, не признающих правомерность таких контактов, сократилось до 75. В 2015 г., таким образом, из стран - членов ООН только 39\% составляли страны, в законодательстве которых имеется запрет на однополые отношения (Carroll, Itaborahy, 2015: 28). Если применять принятую в философии культуры и культурологии дилемму «Запад - Восток», то в этом числе нет ни одной страны, относимой к «Западу». Это важное свидетельство того, что в диалоге культур наметилось новое противостояние.

\section{РОССИЙСКАЯ СИТУАЦИЯ}

А какова ситуация в России? Проанализируем исследования общественного мнения по проблеме отношения к гомосексуализму. Вначале рассмотрим результаты опроса Аевада-центра 2013 г. (Страх ... , 2013: Электронный ресурс). Вопрос о причинах гомосексуальности высветил широкий размах мнений: $34 \%$ респондентов считают, что гомосексуализм - это болезнь, которую надо лечить; 16\% полагают, что такая сексуальная ориентация является врожденной; 23\% видят первопричину в плохом воспитании, а еще 17\% - в совращении (в семье, на улице, в закрытом учреждении).

Результаты опроса 2013 г. показали, что только 23\% респондентов считают, что гомосексуалистов надо предоставить самим себе (в 2005 г. - 30\%, в 2010 г. - 25\%), остальные видят необходимость в принятии по отношению к ним тех или иных мер: оказывать психологическую и иную помощь - 27\% (в 2005 г. - 27\%, в 2010 г. - 24\%); лечить - 22\% (в 2005 г. - 17\%, в 2010 г. - 21\%); изолировать от общества - $16 \%$ (в 2005 г. - 12\%, в 2010 г. - 18\%); физически уничтожать - 5\% (в 2005 г. - 3\%, в 2010 г. - 4\%). Вариант с предоставлением психологической и иной помощи можно интерпретировать по-разному: с одной стороны, здесь прослеживается либеральное отношение к гомосексуалистам и желание им помочь, а с другой - проявляется негативное к ним отношение, намерение исправить их посредством психологической помощи и сделать нормальными людьми. Не будем забывать о том, что в российском обществе пока не укоренилась практика обращения за профессиональной психологической консультацией. В обыденном сознании к психологической помощи прибегают лица с серьезными проблемами, да и то в крайне редких случаях. Наличие различных смыслов, вкладываемых респондентами в понятие «оказание психологической и иной помощи» гомосексуалистам, подтверждается аналогичным вопросом, заданным примерно в те же годы, но предполагающим несколько иные варианты ответа. Только 9\% полагают, что гомосексуалистам надо оказывать психологическую и иную помощь (в отличие от 27\% в 2005 и 2013 г.). В ситуации, когда вместо варианта «физически уничтожать» был предложен вариант «ликвидировать», процент людей, выбирающих эту альтернативу в 2008 г., был значительно выше - 19\%. Еще 30\% респондентов счи- 
тают, что гомосексуалистов надо изолировать от общества, а 28\% готовы предоставить их самим себе.

Вопрос о гей-парадах в очередной раз показал негативное отношение россиян к возможности проведения этого мероприятия. В 2013 г. большинство (87\%) опрошенных высказались против проведения гей-парадов в крупных городах (в 2010 г. - 82\%, в 2005 г. $-84 \%)$.

Идею о разрешении однополых браков поддерживают только 5\% (в 2010 г. - 14\%, в 2012 г. - 10\%), причем о ее полном одобрении высказался всего лишь 1\% (в 2010 и 2012 гг. по 3\%), остальные 4\% относятся к ней скорее положительно (в 2010 г. $11 \%$, в 2012 г. - 7\%). Здесь заметно изменение позиции под влиянием информационной среды той категории населения, которая окончательно не определилась в своем отношении к этой проблеме. Большинство (85\%) опрошенных россиян высказались против легализации однополых браков (в 2010 г. - 84\%, в 2012 г. - 77\%). Только $5 \%$ респондентов готовы дать однополым парам право усыновлять детей, тогда как $80 \%$ высказали негативное мнение по этому вопросу.

Большинство (67\%) респондентов поддержало закон о запрете пропаганды гомосексуализма, тогда как иной позиции придерживались только 14\%. И в этом нет ничего удивительного, поскольку информационные сюжеты о гомосексуализме получают все более широкое распространение, эта проблема активно муссируется СМИ, что вызывает тревогу у россиян за судьбу своих детей. Так, большинство (61\%) респондентов боятся, что их дети или внуки могут стать жертвой пропаганды гомосексуализма.

Опрос ВЦИОМ 2013 г. (Пресс-выпуск № 2320 .., , 2013: Электронный ресурс) также показал, что радужный флаг (один из самых популярных и известных $\Lambda$ ГТТ-символов) в России, по крайней мере, в ближайшем будущем развеваться не будет. Более того, специалисты ВЦИОМ нарисовали еще более мрачную для гомосексуалистов картину, нежели их коллеги из Аевада-центра. Так, например, если по данным ВЦИОМ введение запрета на пропаганду гомосексуализма в России поддерживают $88 \%$ респондентов, то по данным Аевада-центра таких насчитывается $67 \%$.

Вопрос о том, стоит ли обществу и государству применять санкции к гомосексуалистам и какого вида они должны быть, показал, что подавляющее большинство (82\%) опрошенных не готовы оставлять это социальное явление без общественной реакции, высказываясь за использование различных формальных и неформальных санкций. В 2013 г. 42\% респондентов заявили, что нетрадиционная сексуальная ориентация должна быть уголовно наказуема (в 2005 г. - 23\%). Наказание в виде штрафа поддержали $15 \%$ (в 2005 г. - 10\%). Четверть (25\%) опрошенных уверены, что это должно быть предметом общественного порицания (в 2005 г. - 19\%). В период между двумя исследованиями в два раза сократилась (с 34 до 15\%) доля тех, кто считает, что государство и общество не должны вмешиваться в частную жизнь человека и применять к нему какие-либо санкции.

Вопрос респондентам об их личном отношении к гомосексуалистам (который несколько отличается от рассмотренного выше вопроса о том, что должно делать общество и государство) выявил не только нетерпимое отношение россиян к этому явлению, но и сохранение неизменной тенденции на протяжении ряда лет, что опровергает нередко встречающиеся в либеральной среде высказывания о нарастании негативного отношения россиян к гомосексуализму вследствие политики властей и их гомофобной риторики. Более того, опрос ВЦИОМ 2015 г. (Пресс-выпуск № 2876 ... , 
2015: Электронный ресурс) зафиксировал небольшие изменения обозначенной тенденции. Противников легализации однополых союзов за два года уменьшилось с 86 до $80 \%$, а сторонников, наоборот, увеличилось с 4 до $8 \%$.

К людям нетрадиционной сексуальной ориентации в российском обществе в целом относятся весьма прохладно. Каждый шестой $(15 \%)$ из опрошенных в 2015 г. считает их обычными мужчинами и женщинами, но не желает общаться с ними лично. Аругие называют гомосексуализм болезнью: медицинского характера $(20 \%)$ или социального $(15 \%)$. Еще $20 \%$ воспринимают их как людей крайне опасных и даже советуют изолировать их от общества (с 2004 г. эта доля выросла более чем в 1,5 раза - с $12 \%$ ). Толерантность в этом вопросе проявляют только $22 \%$ опрошенных: они не считают, что людей следует как-то дифференцировать по их сексуальным предпочтениям. Чаще других данной точки зрения придерживаются респонденты, знакомые с представителями сексуальных меньшинств лично (55\% - это в два раза больше, чем в среднем по выборке), молодежь (30\% от 18 до 24 лет), атеисты (30\%), жители Москвы и Санкт-Петербурга (28\%).

В вопросе о том, какую позицию должно занять государство по отношению к однополым парам, мнения респондентов разделились, однако наделить их правами обычных гетеросексуальных супругов предлагает незначительное количество опрошенных. Так, только $3 \%$ участников опроса согласны с тем, что гомосексуалистам следует предоставить право на создание полноценной семьи, в том числе на воспитание приемных детей. Еще 3\% предлагают разрешить им вступать в брак, но без возможности усыновления. Каждый десятый $(12 \%)$ полагает, что власти должны защищать гомосексуалистов от дискриминации, но при этом не позволять им заключать брачный союз и брать на воспитание детей. Треть опрошенных (32\%) предлагают не обращать особого внимания на гомосексуалистов, а тем в свою очередь публично не проявлять их сексуальные особенности. Относительное большинство $(41 \%)$ респондентов считает, что гомосексуалистов необходимо подвергнуть преследованиям, искоренив это явление как таковое.

Итак, результаты опросов общественного мнения по проблеме гомосексуализма, проведенных в течение последнего десятилетия, показывают не только сохранение, но и нарастание негативного отношения россиян к этому явлению, которое воспринимается как явная девиация, что противоречит мировой тенденции либерализации половой морали. Волна демократических перемен 1990-х годов, захлестнувшая Россию и подточившая ее моральные основы, видимо, так и не смогла расшатать определенные конструкции ценностного ядра в типичных тезаурусах россиян. Причем в последние годы Россия, как и ее национальный лидер В. В. Путин, позиционирует себя как оплот традиционных ценностей, противостоящий разрушительному влиянию социальных изменений в сфере половой морали, разворачивающихся в странах Европы и США. По вопросу гомосексуализма проходит четкая ценностная граница между Россией и странами Запада, формируя соответствующую идентификацию.

\section{ЗАКАЮЧЕНИЕ}

Ииберализация половой морали представляется нам опасной с точки зрения ее социальных последствий, поскольку без системы социального регулирования секс может и не приводить к рождению детей, обрекая общество на депопуляцию. Именно поэтому представляется неоднозначным утверждение Э. Гидденса о том, что отделе- 
ние прокреативной функции сексуальности от рекреативной является прогрессивным явлением (Гидденс, 2004: 54). Если с точки зрения индивида это может признаваться таковым, то с точки зрения общества вовсе нет, поскольку угрожает его демографическим ресурсам.

В Европе проблему принято не замечать. Тема негативных социальных последствий либерализации половой морали табуирована. Острота демографической проблемы во многом снималась массовым притоком мигрантов, который порождает новые социальные риски. В ряде европейских стран происходит постепенное изменение этнического ландшафта, поскольку мигранты, которые были призваны решить экономические проблемы во второй половине XX в., в основном исповедуют ислам и сохраняют традиционные представления о семейно-брачных отношениях, что проявляется в высоком уровне рождаемости среди них (свою роль играет и социальная политика, стимулирующая рождение нескольких детей). А поскольку приезжие-мусульмане из Африки и Ближнего Востока, как это ярко показал немецкий политик Тило Саррацин в своей работе «Германия: самоликвидация» (Саррацин, 2013), поддерживают высокую степень культурной автономии от коренного населения, не стремясь к интеграции в новом для них социуме, то это может привести к серьезному социальному напряжению в странах, принимающих таких мигрантов. Одной из основных угроз выступают конфликты на почве столкновения культур, особенно при условии спада экономики. Волна терроризма, накатывающая на страны Запада, служит тревожным сигналом в надвигающемся противостоянии. Половая мораль в этой связи может стать одним из аспектов идеологического сражения.

Аиберализация половой морали, разрушая основополагающие традиционные ценностно-нормативные структуры, поддерживающие социальную устойчивость, погружает западное общество в состояние аномии. Но это новый вид этого явления, во многом отличающийся от тех, которые были описаны Э. Аюркгеймом и Р. Мертоном для западного общества начала и середины XX в. Сейчас, в период стремительных социальных изменений, когда отсутствуют прочные нормативные конструкции, в результате чего индивиды готовы достаточно быстро менять свои взгляды и убеждения, аномия становится нормой. В противном случае надо признать, что большинство индивидов, принимая в качестве нормы деструктивные виды поведения, нарушающие функционирование социальных структур, являются девиантами.

Социальные изменения в сексуальной сфере происходят с чрезвычайно высокой скоростью. Традиционные ценности, определявшие мировоззрение индивидов на протяжении веков, рухнули под напором новых демократических веяний, в основе которых лежат права и свободы человека. Пытаясь обрести максимально широкую степень независимости от социальных структур, человек разрывает моральные путы и получает иллюзию своей свободы. Но почему это произошло именно сейчас, почему общество позволило ему это сделать, только ли высокая степень развития демократии способствовала этому? Осмысление этих вопросов еще впереди. В детальном исследовании нуждаются также последствия либерализации половой морали с точки зрения процессов социализации новых поколений и формирования их идентичности в условиях, когда нормативный порядок больше не воспроизводится. Очевидно, что западному обществу в XXI в. предстоит вести сложный поиск пути устойчивого социального развития, сочетающего в себе баланс интересов личности и общества, который пока имеет явный крен в сторону индивида. 


\section{СПИСОК АИТЕРАТУРЫ}

Абеляр, П. (2014) История моих бедствий. СПб. : Азбука ; Азбука-Аттикус. 288 с.

Августин, А. (2014) Исповедь. СПб. : Азбука ; Азбука-Аттикус. 400 с.

Американцы сочли четверть жителей США геями и лесбиянками. (2015) [Электронный ресурс]// Lenta.ru. 22 мая. URL: http://lenta.ru/news/2015/05/22/american_gays/ [архивировано в WebCite] (дата обращения: 20.07.2015).

Бергер, П., Аукман, Т. (1995) Социальное конструирование реальности : Трактат по социологии знания. М. : Медиум. 323 с.

Верховный суд США легализовал однополые браки во всех штатах. (2015) [Электронный ресурс] // Интерфакс. 26 июня. URL: http://interfax.ru/world/450026 [архивировано в WebCite] (дата обращения: 20.07.2015).

В Ирландии начался референдум о легализации однополых браков. (2015) [Электронный ресурс]//Lenta.ru. 22 мая. URL: http://lenta.ru/news/2015/05/22/irish_gays/[архивировано в Web Cite] (дата обращения: 20.07.2015).

В США христиане все чаще подвергаются дискриминации со стороны гей-сообщества. (2013) [Электронный ресурс]// Пролайф Беларусь. 22 сентября. URL: http://pro-life.by/antisemejnyetehnologii/homosexuality/v-ssha-hristiane-vse-chashhe-podvergayutsya-diskriminatsii-so-storonygej-soobshhestva/ [архивировано в WebCite] (дата обращения: 20.07.2015).

В Финляндии легализовали однополые браки. (2015) [Электронный ресурс] // Lenta.ru. 20 февраля. URL: http://lenta.ru/news/2015/02/20/finland_gays/ [архивировано в WebCite] (дата обращения: 20.07.2015).

Гидденс, Э. (2004) Трансформация интимности. СПб. : Питер. 208 с.

Глава Mozilla ушел из-за неприятия однополых браков. (2014) [Электронный ресурс]// ВBC Русская служба. 4 апреля. URL: http://bbc.com/russian/society/2014/04/140128_mozilla_boss_ resigns [архивировано в WebCite] (дата обращения: 20.07.2015).

Ирландцы на референдуме поддержали однополые браки. (2015) [Электронный ресурс] // NEWSru.com. 23 мая. URL: http://newsru.com/world/23may2015/lgbtrights.html [архивировано в WebCite] (дата обращения: 20.07.2015).

Керри: США продолжат добиваться равных прав для секс-меньшинств в мире. (2015) [Электронный ресурс]// РИА Новости. 27 июня. URL: http://ria.ru/world/20150627/1092127689.html [архивировано в WebCite] (дата обращения: 20.07.2015).

Климеш, А. (2015) Чехии не избежать однополых браков [Электронный ресурс] // ИноСМИ.Ru. 14 июля. URL: http://inosmi.ru/world/20150714/229076863.html [архивировано в Web Cite] (дата обращения: 20.07.2015).

Ковалева, А. И. (2012) Методологические проблемы исследования социализации // Знание. Понимание. Умение. № 2. С. 19-24.

Ковалева, А. И., Ауков, В. А. (2012) Социализация: социально-философский, социологический и социально-психологический аспекты понимания // Философия и культура. № 3. C. $27-35$.

Кузнецова, Т. Ф., Ауков, Вл. А. (2009) Культурная картина мира в свете тенденций развития культурологии // Вестник Международной академии наук (Русская секция). № 1. С. 66-69.

Куприянов, А. (2015) Радуга над Госдепом [Электронный ресурс] // Lenta.ru. 5 мая. URL: http://lenta.ru/articles/2015/05/05/diplogay/ [архивировано в WebCite] (дата обращения: 20.07.2015).

Ауков, В. А. (2012) Теории молодежи: Междисциплинарный анализ. М. : «Канон+» РООИ «Реабилитация». $528 \mathrm{c.}$

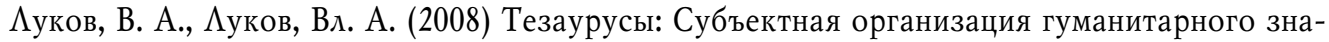
ния. М. : ИзА-во Нац. ин-та бизнеса. 784 с.

Ауков, В. А., Ауков, Вл. А. (2013) Тезаурусы II: Тезаурусный подход к пониманию человека и его мира. М. : Изд-во Нац. ин-та бизнеса. 640 с.

Ауков, В. А., Тихомиров, А. А. (2012) Аобрачные сексуальные отношения молодежи: дилемма социальной нормы и отклонения. М. : ИзА-во Моск. гуманит. ун-та. 188 с. 
Погорский, Э. К. (2012) Человек в сетевом пространстве // Знание. Понимание. Умение. № 3. С. 304-309.

Погорский, Э. К. (2013) Конструирование картин мира молодежи // PolitBook. № 2. С. 183-191.

Пресс-выпуск № 2320. Закон о пропаганде гомосексуализма: за и против. (2013) [Электронный ресурс]// ВЦИОМ. 11 июня. URL: http://wciom.ru/index.php?id=236\&uid=114190 [архивировано в WebCite] (дата обращения: 20.07.2015).

Пресс-выпуск № 2876. Однополые браки: за и против (2015) [Электронный ресурс]// ВЦИОМ. 9 июля. URL: http://wciom.ru/index.php?id=236\&uid=115315 [архивировано в WebCite] (дата обращения: 20.07.2015).

Референдум в Ирландии вдохновил геев Австралии. (2015) [Электронный ресурс] // ВBC Русская служба. 1 июня. URL: http://bbc.com/russian/multimedia/2015/06/150601_v_australia_ rally [архивировано в WebCite] (дата обращения: 20.07.2015).

Руссо, Ж. Ж. (2014) Исповедь. СПб. : Азбука ; Азбука-Аттикус. 640 с.

Саррацин, Т. (2013) Германия: самоликвидация. М. : АСТ. 400 с.

Страх другого. Проблема гомофобии в России. (2013) [Электронный ресурс] // МевадаЦентр. 12 марта. URL: http://levada.ru/12-03-2013/strakh-drugogo-problema-gomofobii-v-rossii [архивировано в WebCite] (дата обращения: 20.07.2015).

Тайдаков, В. И., Цветкова, Г. А. (2003) Мораль // Социологическая энциклопедия : в 2 т. М. : Мысль. Т. 1.694 с. С. 683-684.

Тихомиров, А. А. (2009) Аобрачные сожительства в Москве как новая составляющая матримониального поведения молодежи // Знание. Понимание. Умение. № 3. С. 106-110.

Толстой, $\Lambda$. Н. (2014) Без любви жить легче. М. : АСТ. 320 с.

9 из 10 молодых католиков в Германии игнорируют учение Церкви о половых отношениях. (2014) [Электронный ресурс]// Katolik.ru. 6 января. URL: http://katolik.ru/mir/117756-9-iz-10molodykh-katolikov-v-germanii-ignoriruyut-uchenie-tserkvi-o-polovykh-otnosheniyakh.html [apхивировано в WebCite] (дата обращения: 20.07.2015).

Carroll, A., Itaborahy, L. P. (2015) State-sponsored homophobia : A world survey of laws: criminalisation, protection and recognition of same-sex love. 10 th edn. Geneva : ILGA. 129 p.

Itaborahy, L. P., Zhu, J. (2014) State-sponsored homophobia : A world survey of laws: criminalisation, protection and recognition of same-sex love. $9^{\text {th }}$ edn. Geneva : ILGA. 95 p.

Newport, F. (2015) Americans greatly overestimate percent gay, lesbian in U.S. [Электронный ресурс]// Gallup.com. 21 мая. URL: http://gallup.com/poll/183383/americans-greatly-overestimatepercent-gay-lesbian.aspx [архивировано в WebCite] (дата обращения: 20.07.2015).

Аата поступления: 20.07.2015 г.

\section{THE LIBERALIZATION OF SEXUAL MORALITY IN THE MODERN WORLD \\ D. A. TIKHOMIROV}

(G. V. PlekHANov RUSSiAN UNIVERSITY of ECONOMICS)

This article discusses the process of liberalization of sexual morality in the modern world. It is shown that normative beliefs about sexual relationships are significantly different between cultures, which enhance their social sustainability by erecting the boundaries of acceptable sexual behavior. In Western society, sexual morality originally based on Christian teachings, though regularly violated by its members, has remained stable for centuries. Individuals who violated the established norms in terms of sexuality never tried to dismantle the entire regulatory order. However, in the second half of the 20th century, dramatic changes occurred that destroyed many of the fundamental values and normative patterns that define human behavior. First the heterosexual youth revolution of the 1960s, which had a predominantly female face, tore down regulation concerning sexuality, marriage and fertility, and then, at the turn of the 21st century, the homosexual revolution permanently deformed traditional sexual morality.

In the West nontraditional sexual relations at the moment are undergoing constitutionalization both in the informal and formal ways. The public opinion has begun to accept certain decisions affect- 
ing the interests of the LGBT community, who, in their turn, increasingly impose their culture on individuals, social groups and society as a whole. Those who disagree with the new rules are increasingly often subjected to various sanctions. Homosexuality moves from socio-cultural to the political field, entering the orbit of the geopolitical interests of Western countries.

Unlike Europe and the USA, where sexual morality is being liberalized (although not in a uniform manner), in some countries the opposite trend is conspicuous. In this article, special attention is paid to Russia. Having analyzed the results of public opinion polls on the issue of homosexuality conducted in the last decades, we show that Russians' negative attitude to this phenomenon is on the rise. Perceiving homosexuality as a deviation contradicts the global trend of liberalizing sexual morality.

Keywords: sexual morality, liberalization of sexual morality, public opinion, sexual revolution, sexual relations, homosexuality.

\section{REFERENCES}

Abelard, P. (2014) Istoriia moikb bedstvii [The history of my calamities]. St. Petersburg, Azbuka Publ. ; Azbuka-Attikus Publ. 288 p. (In Russ.).

Augustine. (2014) Ispoved' [Confession]. St. Petersburg, Azbuka Publ. ; Azbuka-Attikup Publ. 400 p. (In Russ.).

Amerikantsy sochli chetvert' zhitelei SShA geiami i lesbiiankami [Americans think $1 / 4$ of the U.S. population gay or lesbian]. (2015) Lenta.ru. May 22. [online] Available at: http://lenta.ru/news/ 2015/05/22/american_gays/ [archived in WebCite] (accessed 20.07.2015). (In Russ.).

Berger, P. and Luckmann, T. (1995) Sotsial' noe konstruirovanie real' nosti : Traktat po sotsiologii znaniia [The social construction of reality: A treatise on sociology of knowledge]. Moscow, Medium Publ. 323 p. (In Russ.).

Verkhovnyi sud SShA legalizoval odnopolye braki vo vsekh shtatakh [USA Supreme Court legalized same-sex marriage in all states]. (2015) Interfax. June 26. [online] Available at: http://interfax.ru/world/450026 [archived in WebCite] (accessed 20.07.2015). (In Russ.).

V Irlandii nachalsia referendum o legalizatsii odnopolykh brakov [Ireland: Referendum on samesex marriage legalization has started]. (2015) Lenta.ru. May 22. [online] Available at: http://lenta.ru/news/2015/05/22/irish_gays/ [archived in WebCite] (accessed 20.07.2015). (In Russ.).

V SShA khristiane vse chashche podvergaiutsia diskriminatsii so storony gei-soobshchestva [Christians in the USA increasingly discriminated against by the gay community]. (2013) Prolaif Belarus' . September 22. [online] Available at: http://pro-life.by/antisemejnye-tehnologii/homosexuality/vssha-hristiane-vse-chashhe-podvergayutsya-diskriminatsii-so-storony-gej-soobshhestva/ [archived in WebCite] (accessed 20.07.2015). (In Russ.).

V Finliandii legalizovali odnopolye braki [Same-sex marriages legalized in Finland]. (2015) Lenta.ru. February 20. [online] Available at: http://lenta.ru/news/2015/02/20/finland_gays/ [archived in WebCite] (accessed 20.07.2015). (In Russ.).

Giddens, A. (2004) Transformatsiia intimnosti [The transformation of intimacy]. St. Petersburg, Piter Publ. 208 p. (In Russ.).

Glava Mozilla ushel iz-za nepriiatiia odnopolykh brakov [Mozilla CEO resigned due to negative position on same-sex marriages]. (2014) BBC Russkaia sluzbba. April 4. [online] Available at: http://bbc.com/russian/society/2014/04/140128_mozilla_boss_resigns [archived in WebCite] (accessed 20.07.2015). (In Russ.).

Irlandtsy na referendume podderzhali odnopolye braki [The Irish supported same-sex marriages at referendum]. (2015) NEWSru.com. May 23. [online] Available at: http://www.newsru.com/world/ 23may2015/lgbtrightp.html [archived in WebCite] (accessed 20.07.2015). (In Russ.).

Kerri: SShA prodolzhat dobivat'sia ravnykh prav dlia seks-men'shinstv v mire [Kerry: USA to continue fight for sexual minorities' rights]. (2015) RIA Novosti. June 27. [online] Available at: http:// ria.ru/world/20150627/1092127689.html [archived in WebCite] (accessed 20.07.2015). (In Russ.).

Klimeљ, D. (2015) Chekhii ne izbezhat' odnopolykh brakov [No avoiding same-sex marriage for the Czech Republic]. InoSMI.ru. July 14. [online] Available at: http://inosmi.ru/world/20150714/ 229076863.html [archived in WebCite] (accessed 20.07.2015). (In Russ.). 
Kovaleva, A. I. (2012) Metodologicheskie problemy issledovaniia sotsializatsii [The methodological problems of the research of socialization]. Znanie. Ponimanie. Umenie, no. 2, pp. 19-24. (In Russ.).

Kovaleva, A. I. and Lukov, Val. A. (2012) Sotsializatsiia: sotsial'no-filosofskii, sotsiologicheskii i sotsial'no-psikhologicheskii aspekty ponimaniia [Socialization: The socio-philosophical, sociological and socio-psychological aspects of understanding]. Filosofiia $i$ kul'tura, no. 3, pp. 27-35. (In Russ.).

Kuznetsova, T. F. and Lukov, Vl. A. (2009) Kul'turnaia kartina mira v svete tendentsii razvitiia kul'turologii [Cultural worldview in the light of development trends of culturology]. Vestnik Mezbdunarodnoi Akademii nauk (Russkaia sektsiia), no. 1, pp. 66-69. (In Russ.).

Kupriianov, A. (2015) Raduga nad Gosdepom [Rainbow above the State Department]. Lenta.ru. May 5. [online] Available at: http://lenta.ru/articles/2015/05/05/diplogay/ [archived in WebCite] (accessed 20.07.2015).

Lukov, Val. A. (2012) Teorii molodezbi: Mezbdistsiplinarnyi analiz [Theories of the youth: An interdisciplinary analysis]. Moscow, "Kanon+" Publ., RPOD "Reabilitatsiia". 528 p. (In Russ.).

Lukov, V. A. and Lukov, Vl. A. (2008) Tezaurusy: Sub»ektnaia organizatsiia gumanitarnogo znaniia [Thesauri: The subjective organization of humanities knowledge]. Moscow, The National Institute of Business Publ. 784 p. (In Russ.).

Lukov, Val. A. and Lukov, Vl. A. (2013) Tezaurusy II : Tezaurusnyi podkhod k ponimaniiu cheloveka $i$ ego mira [Thesauri II: The thesaurus approach to the conceptualization of the person and his/her world]. Moscow, The National Institute of Business Publ. 640 p. (In Russ.).

Lukov, Val. A. and Tikhomirov, D. A. (2012) Dobrachnye seksual' nye otnosheniia molodezhi: dilemma sotsial'noi normy $i$ otkloneniia [Premarital sexual relations of the youth: The dilemma of social norm and deviation]. Moscow, Moscow University for the Humanities Publ. 188 p. (In Russ.).

Pogorskiy, E. K. (2012) Chelovek v setevom prostranstve [Human being in the network space]. Znanie. Ponimanie. Umenie, no. 3, pp. 304-309. (In Russ.).

Pogorskiy, E. K. (2013) Konstruirovanie kartin mira molodezhi [The construction of youth's world views]. PolitBook, no. 2, pp. 183-191. (In Russ.).

Press-vypusk № 2320. Zakon o propagande gomoseksualizma: za i protiv [Press release no. 2320. The anti-gay propaganda law: Pro and contra]. (2013) VTSIOM. June 11. [online] Available at: http:// wciom.ru/index.php?id=236\&uid=114190 [archived in WebCite] (accessed 20.07.2015). (In Russ.).

Press-vypusk № 2876. Odnopolye braki: za i protiv [Press release no. 2876. Same-sex marriages: pro and contra]. (2015) VTSIOM. July 9. [online] Available at: http://wciom.ru/index.php?id= 236\&uid=115315 [archived in WebCite] (accessed 20.07.2015). (In Russ.).

Referendum v Irlandii vdokhnovil geev Avstralii [Irish referendum inspired gays in Australia]. (2015) BBC Russkaia sluzbba. June 1. [online] Available at: http://bbc.com/russian/multimedia/ 2015/06/150601_v_australia_rally [archived in WebCite] (accessed 20.07.2015). (In Russ.).

Rousseau, J.-J. (2014) Ispoved' [The confessions]. St. Petersburg, Azbuka Publ. ; Azbuka-Attikus Publ. 640 p. (In Russ.).

Sarrazin, Th. (2013) Germaniia: samolikvidatsiia [Germany is doing away with itself]. Moscow, AST Publ. 400 p. (In Russ.).

Strakh drugogo. Problema gomofobii v Rossii [Fear of the Other: Homophobia issues in Russia]. (2013) Levada-Tsentr. March 12. [online] Available at: http://levada.ru/12-03-2013/strakh-drugogoproblema-gomofobii-v-rossii [archived in WebCite] (accessed 20.07.2015). (In Russ.).

Taidakov, V. I. and Tsvetkova, G. A. (2003) Moral' [Morality]. In: Sotsiologicheskaia entsiklopediia [Encyclopedia of sociology] : in 2 vols. Moscow, Mysl' Publ. Vol. 1. Pp. 683-684. (In Russ.).

Tikhomirov, D. A. (2009) Dobrachnye sozhitel'stva v Moskve kak novaia sostavliaiushchaia matrimonial'nogo povedeniia molodezhi [Illegitimate cohabitation in Moscow as a new component of matrimonial behaviour of youth]. Znanie. Ponimanie. Umenie, no. 3, pp. 106-110. (In Russ.).

Tolstoy, L. N. (2014) Bez liubvi zhit' legche [Without love life is easier]. Moscow, AST Publ. 320 p. (In Russ.).

9 iz 10 molodykh katolikov v Germanii ignoriruiut uchenie Tserkvi o polovykh otnosheniiakh [9 of 10 young Roman Catholics in Germany ignore the Church's teachings on sexual relations]. (2014) 
Katolik.ru January 6. [online] Available at: http://katolik.ru/mir/117756-9-iz-10-molodykh-katolikov-v-germanii-ignoriruyut-uchenie-tserkvi-o-polovykh-otnosheniyakh.html [archived in Web Cite] (accessed 20.07.2015). (In Russ.).

Carroll, A. and Itaborahy, L. P. (2015) State-sponsored bomophobia : A world survey of laws: criminalisation, protection and recognition of same-sex love. $10^{\text {th }}$ edn. Geneva, ILGA. $129 \mathrm{p}$.

Itaborahy, L. P. and Zhu, J. (2014) State-sponsored homophobia : A world survey of laws: criminalisation, protection and recognition of same-sex love. $9^{\text {th }}$ edn. Geneva, ILGA. 95 p.

Newport, F. (2015) Americans greatly overestimate percent gay, lesbian in U.S. Gallup.com. May 21. [online] Available at: http://gallup.com/poll/183383/americans-greatly-overestimate-percentgay-lesbian.aspx [archived in WebCite] (accessed 20.07.2015).

Submission date: 20.07.2015.

Тихомиров Амитрий Андреевич - кандидат социологических наук, доцент кафедры политологии и социологии Российского экономического университета им. Г. В. Плеханова. Адрес: 117997, Россия, г. Москва, Стремянный пер., А. 28, корп. 1. Тел.: +7 (495) 958-23-27. Эл. адрес: dat1983@yandex.ru

Tikhomirov Dmitry Andreevich, Candidate of Sociology, Associate Professor, Department of Political Science and Sociology, G. V. Plekhanov Russian University of Economics. Postal address: Bldg. 1, 28 Stremyannyi Lane, 117997 Moscow, Russian Federation. Tel.: +7 (495) 958-23-27. E-mail: dat1983@yandex.ru 